\title{
Reflecting on the Oppressor in the Mirror
}

\section{Marc Peters*}

Abstract Drawing extensively from personal experience, the author explores what it is like to experience patriarchy from the perspective of a person of privilege. He tracks his journey as a young white man coming to terms with the undue privilege that he is afforded on the basis of his race and gender. The article also explores the flaws the author finds in rigid identity politics that hinder collaboration, and attempts to illustrate how people lose and the system wins when activists engage in in-fighting and cling tightly to narrow definitions of identity. Ultimately, the article makes the case for how shared humanity is a key component in making significant progress in social change efforts and in society as a whole.

I am tired of talking about race. I am tired of talking about gender. I am tired of talking about violence, societal privilege, power and oppression. I'm tired of all of it. Instead of continuing to raise my voice against injustice, I would rather stay silent for a while. As a straight white man in America, I am afforded that privilege. Since patriarchy favours me, I can turn a blind eye to suffering and a deaf ear to calls for justice and still be just fine. Privilege means the ability to ignore the realities of those who do not experience the world the same way that you do. Even those who recognise the systems of oppression in place and believe in a fairer and more just world can often lack the sense of urgency needed to bring about change.

Reverend Dr Martin Luther King, Jr described this group of people, my peer group of 'white moderates', brilliantly in his Letter from a Birmingham Jail:

I must confess that over the past few years I have been gravely disappointed with the white moderate... who is more devoted to 'order' than to justice; who prefers a negative peace which is the absence of tension to a positive peace which is the presence of justice; who constantly says: 'I agree with you in the goal you seek, but I cannot agree with your methods of direct action'; who paternalistically believes he can set the timetable for another man's freedom; who lives by a mythical concept of time and who constantly advises the Negro to wait for a 'more convenient season'.

Shallow understanding from people of good will is more frustrating than absolute misunderstanding from people of ill will. Lukewarm acceptance is much more bewildering than outright rejection (King 1963).

The underlying questions of Dr King's time remain today: how do we get people with tremendous societal privilege to work feverishly for equality when they do not share a fierce urgency of now?

I should be in a unique position to answer that as a straight white man who has persistently challenged notions of racism, sexism and homophobia. However, the more and more I reflect on that question, the less and less I feel qualified to answer it. The problem is that I have never felt at home in groups predominately comprised of white men. I can trace that back to my childhood when I spent much of my time being mercilessly bullied by my white male peers. Whether it was my sensitivity, willingness to listen and share my feelings or my proclivity for picking up a book before tossing around a football, I've never fitted into the box of stereotypical masculinity. As a result, even before I knew what systems of oppression were or how I 
benefited from them, I had a natural inclination to shy away from those in my identity group. I struggled mightily with severely diminished selfesteem, the result of being torn down too many times. The respite for me came when I was about 12 years old and found a group of people who accepted me for who I was and allowed me to feel comfortable in my own skin. It just so happened that group of people were all young black men.

In 1997, Dr Beverly Daniel Tatum published a book entitled Why Are All of the Black Kids Sitting Together in the Cafeteria? that examined racial realities of schools in the United States. One of the major claims was that as children got older they tended to cluster by race in social spaces. That was very much the case at my school. I was the exception. Out of a desire to fit in with my new friends, I embarked on quite the wellintentioned cultural misappropriation. I wore the latest clothes put out by the hottest rappers and became obsessed with hip hop music, a genre that did not remotely reflect my life experience. Some other white students at my school were dismayed by what they considered something of a cultural betrayal so the taunts I previously experienced were supplemented by those of ' $\mathrm{n} * * * * \mathrm{r}$ lover' and other racial slurs. As I grew up and became more aware of the world around me, it became less about culture, music and clothes and more about the subtle indicators that my friends and I were destined to lead very different lives.

In high school, I began to notice the lack of African-American students in the upper level classes at my school and wondered why none of the really bright kids that I hung out with in middle school were on my 'academic track'. I realised that nothing I could do would result in me sharing the same life experiences as my black friends and I stopped trying so hard to fit in and focused on just hanging out. After we turned 18, some of my friends and I would go out to clubs together and even if we were wearing identical outfits, they would assuredly be harassed by bouncers over the dress code while I was free to go on unmolested. The profiling was certainly not limited to the line getting in and I remember vividly having to keep a friend of mine from getting goaded into an altercation with a police officer. My friends and I would resort to gallows humour to avoid dealing with the harsh racial realities that have persisted throughout far too many generations in America.
As time moved on, I did my best to move past the surface level of cultural understanding and spent more time learning about the history of black people in the United States. I started to read the speeches and writings of Martin Luther King, Jr and Malcolm X, the poetry of Nikki Giovanni and the prose of bell hooks. By witnessing the experiences of my friends and immersing myself in studying African-American history, I learned about how the privileges afforded to me were embedded into society. No matter how hard I tried, I could not disavow them. It took me until college to come to the same level of realisation with regard to gender.

I certainly did not subscribe to sexist beliefs growing up, but when it came to understanding the nature of patriarchy, I stayed ignorant and unaware. I had the wonderful fortune to join a student group called 'A Men's Issue' at Syracuse University where I had the space to work with other men on how we could play a role in addressing issues like gender-based violence that were generally considered the domain of women. Since starting on a path of gender justice work, I have been exposed to some pretty heinous stories of what it is possible for humans to do to one another. I have seen what the aftermath of sexual assault looks like for the survivor. I have seen what years of emotional abuse will do to the strongest person. I've seen things that I wish I could un-see. I learned the far too often ignored human costs that come from maintaining an unjust system. I recognise that without fundamental change to the systems of oppression that exist in the world today, I will continue to be awarded unearned privilege and others will continue to suffer undue burdens.

The best I can hope to do is work as an ally to combat systemic oppression and ensure equality for all people. I'm tremendously grateful for how much my childhood informed my sense of self and my ability to understand a level of shared humanity that remains regardless of skin colour, sexual orientation or gender identity. There are certainly times I am given undue credit just for being a straight white man and caring about equity and equality. Speaking up and speaking out should not be special. It should be commonplace.

If we are going to have an inclusive world, we must first have an inclusive movement for equality and, in my country at least, it is becoming more and 
more evident that we do not. My white peers, my cisgendered peers, my straight peers and my male peers should be paying special attention to this conversation that is taking place all around us and recently with renewed vigour. A spotlight was shone on this issue very recently with the emergence of the \#SolidarityIsForWhiteWomen discussion on Twitter. Activist Mikki Kendall who started the online conversation talked about its meaning in an article in The Guardian:

\section{When I launched the hashtag}

\#SolidarityIsForWhiteWomen, I thought it would largely be a discussion between people impacted by the latest bout of problematic behaviour from mainstream white feminists. It was intended to be Twitter shorthand for how often feminists of colour are told that the racism they experience 'isn't a feminist issue'. The first few tweets reflect the deeply personal impact of such a long-running structural issue.

As the hashtag spread across Twitter, people from all walks of life started joining in - to vent their own personal frustrations, as well as to address larger political issues. Feminism as a global movement meant to unite all women has global responsibilities, and - as illustrated by hundreds of tweets - has failed at one of the most basic: it has not been welcoming to all women, or even their communities

(Kendall 2013).

Activism that occurs online is often diminished and dismissed by those that think that change cannot happen 140 characters at a time. However, the conversation started by Kendall has led to a renewed dialogue about intersectionality and inclusion with many others weighing in, not only on Twitter, but in their own long-form articles. Lauren Walker wrote on how she has struggled to reconcile her race and her place in the feminist movement:

I kept noticing more and more examples of pointed erasure of women who looked like me from feminism, and my dissatisfaction became greater and greater. I had never heard of the work of black and brown feminists as a child not because we were unworthy, nonexistent, or only there to be saved; it was because they was [sic] being consciously disregarded (Walker 2013).

When we try and isolate identities and talk about them individually, we are asking people to be less than their whole selves. We must find a way to move past identity politics while still recognising the value of every identity. We continue to subscribe to false narratives and binaries around gender and race and sexual orientation and make value judgements over whose freedom and rights we can fight for at any given moment. Who are we to choose whose rights are most important when everyone's rights are important? We engage in arguments about power as if only a finite amount of it exists and that if we lift up classes of people that we do not belong to then they win and we lose. We create sides in a war and attack each other rather than working towards a shared vision of the future that upholds equality for all rather than privilege for a few. As a result, the system wins. And when the system wins, the dominant group wins.

Theoretically, as a member of so many dominant groups, I win in that circumstance. However, it certainly feels like a pyrrhic victory.

Our collective struggles for freedom and equality are forever intertwined. As Dr King said, in his same letter admonishing white moderates, 'We are caught in an inescapable network of mutuality, tied in a single garment of destiny. Whatever affects one directly, affects all indirectly' (King 1963). For a long time, I thought of shared humanity as the necessary starting point when working for social change, but perhaps it is the destination. If we truly see ourselves in the other then how could we rape? If we truly see ourselves in the other, how could we inflict the emotional trauma of bullying or the physical trauma of gun violence and war? If we truly see ourselves in the other, how can we hate? We have to move beyond combating the injustices present in the world today and move towards developing a shared vision for the world that we want to create.

Fighting against something is always the quickest way to rally people together, but it is also the most sure-fire way to solidify the position of our 'opponents'.

If we want a radical change that befits the future that we seek to create then we must embrace those in halls of power and positions of privilege who may not share our worldview. Others may or may not share this inclination, but I know that I for one stopped seeing the humanity in people who remain totally ignorant to their privilege. While the conversations with people that disagree with us are harder, they are all the more 
important in spite of that difficulty. I am realising now that if I want to inspire my peers to get involved in creating a more just and equal world, I have to start from a place of recognising their human value, even if they do not yet see that same value in others. I cannot continue to assume that those afforded the most privilege by a patriarchal system somehow operate outside of it and from a place of deep hatred. I of all people should know that white men do not serve as the puppet masters pulling the strings somehow controlling how patriarchy manifests and operates. Patriarchy casts a shadow over all of us and while my peer group benefits the most from it and have the least motivation to change it, we still live within the constructs of it. As hard as it is for me to accept, we cannot undress patriarchy if we do not liberate the patriarchs.

When I step before a room of people to talk about equality, assumptions of my worldview abound based on my privilege. When I confound those embarrassingly low expectations, I have no problem finding common ground and shared humanity with those who are systematically oppressed. I struggle to engage dominant groups in these conversations when simply by raising the issues, I implicate the individual for behaviour that they might not even engage in personally. Writer Laurie Penny brought an insightful perspective to systemic sexism recently that speaks to the challenges of engaging men in these conversations:

What we don't say is: of course not all men hate women. But culture hates women, so men who grow up in a sexist culture have a tendency to do and say sexist things, often without meaning to. We aren't judging you for who you are but that doesn't mean we're not asking you to change your behaviour. What you feel about women in your heart is of less immediate importance than how you treat them on a daily basis.

You can be the gentlest, sweetest man in the world yet still benefit from sexism. That's how oppression works. Thousands of otherwise decent people are persuaded to go along with an unfair system because it's less hassle that way. The appropriate response when somebody demands a change in that unfair system is to listen, rather than turning away or yelling, as a child might, that it's not your fault. And it isn't your fault. I'm sure you're lovely. That doesn't mean you don't have a responsibility to do something about it (Penny 2013).

In order for someone to feel that they have a responsibility to do something, they must first acknowledge the existence of a problem. Privilege truly does blind us to the problems we do not experience ourselves and as a result we have to invest the time necessary to educate and liberate those who live as oppressors, either ignorantly or intentionally. I must acknowledge that it is inherently unfair for those being oppressed, either individually or systemically, to bear the burden of liberating their oppressors. I know many people, myself included, recoil from it on the basis of that unfairness. However, it is very much necessary. During his work as a lawyer for the National Association for the Advancement of Colored People (NAACP), future US Supreme Court Justice Thurgood Marshall was quoted saying, 'Sometimes I get awfully tired of trying to save the white man's soul.' Yet, he still went about doing just that.

I draw inspiration from the fact that throughout history some of the most profound social change has come when people unite beyond race, gender and class identity to work together for a shared vision for a community, a country or the world.

The most powerful social movements in the history of the world have given the oppressor the opportunity to redeem himself or herself. Take the anti-apartheid movement in South Africa: Nelson Mandela actively sought to include White South Africans in the reconciliation process because he knew that if the country tore itself apart in war it would never sustain peace. $\mathrm{He}$ distilled his philosophy into how he approached people:

It's a good thing to assume, to act on the basis that others are men of integrity and honor, because you tend to attract integrity and honor if that is how you regard those with whom you work. I believe in that (Stengel 2010).

As we move forward, let us embrace the humanity of those with privilege and power, let us believe in their integrity and honour, and let us find a way to work together for the change we are seeking. 


\section{Note}

* Marc Peters is the Global Communications and Campaigns Manager for MenEngage. MenEngage is a global alliance made up of dozens of country networks spread across many regions of the world, hundreds of nongovernmental organisations, as well as UN partners. They engage men and boys in

\section{References}

Kendall, M. (2013) '\#SolidarityIsForWhiteWomen: Women of Color's Issue with Digital Feminism', The Guardian, www.theguardian.com/ commentisfree/2013/aug/14/solidarityisfor whitewomen-hashtag-feminism (accessed 14 August 2013)

King, Jr, M. (1963) Letter from a Birmingham Jail, African Studies Center, University of Pennslyvania, www.africa.upenn.edu/ Articles_Gen/Letter_Birmingham.html (accessed 16 April 2013)

Penny, L. (2013) 'Of Course All Men don't Hate Women. But All Men Must Know they Benefit from Sexism', New Statesman, reducing gender inequalities and promoting the health and wellbeing of women, men and children. MenEngage partners work collectively and individually towards advancing gender justice, human rights and social justice to achieve a world in which all can enjoy healthy, fulfilling and equitable relationships and their full potential.

www.newstatesman.com/2013/08/lauriepenny/men-sexism (accessed 16 August 2013)

Stengel, R. (2010) Mandela's Way: Lessons on Life, Love, and Courage, Kindle Edition, Crown Publishing Group, Kindle locations 1093-6

Tatum, B.D. (1997) Why Are All of the Black Kids Sitting Together in the Cafeteria?, New York: Basic Books

Walker, L. (2013) Why \# SolidarityIsForWhiteWomen has Been so Meaningful to Me, and Why it Must Never be Forgotten, XoJane, www.xojane.com/issues/ why-solidarityisforwhitewomen-should-neverbe-forgotten (accessed 15 August 2013) 